\title{
EFEKTIVITAS OBAT KUMUR POVIDONE IODINE UNTUK MEMINIMALISIR VIRAL LOAD DAN TRANSMISI COVID-19 MELALUI DROPLET
}

\author{
Deva Juniar \\ Fakultas Kedokteran, Universitas Lampung, Jl. Prof. DR. Ir. Sumatri Brojonegoro No.1, Gedong \\ Meneng, Kec. Rajabasa, Kota Bandar Lampung, Lampung, Indonesia 35145 \\ Devajuniar76@gmail.com (+6281273214687)
}

\begin{abstract}
ABSTRAK
WHO telah menyatakan COVID-19 sebagai pandemi global. Hingga saat ini jumlah kasus yang terkonfirmasi positif di Indonesia sebanyak 1.051.795 kasus dengan jumlah kematian sebesar 29.518 jiwa. Salah satu obat kumur antimikroba spektrum luas yang paling banyak tersedia untuk mengurangi patogen adalah obat kumur povidone iodin (PVP-I). PVP-I diketahui memiliki aktivitas mikrobisidal yang kuat. Tujuan penelitian ini adalah untuk mengetahui efektivitas obat kumur PVP-I untuk meminimalisir viral load dan trnsmisi COVID-19 melalui droplet. Artikel ini disusun dengan mencari sumber literatur menggunakan database NCBI, PubMed, Google Scholar, Research Gate dan Science Direct, didapatkan sebanyak 39 artikel yang diterbitkan pada tahun 2015 hingga 2021 menggunakan kata kunci yang berkaitan dengan judul yaitu PVP-I, obat kumur povidone iodine, COVID-19. Setelah diseleksi berdasarkan focus pembahasannya mengenai efektivitas obat kumur PVP-I dalam meminimalisir viral load dan transmisi COVID-19 melalui droplet, penulis menggunakan 22 artikel sebagai referensi utama. Penggunaan PVP-I sebagai obat kumur direkomendasikan untuk mengurangi viral load di rongga mulut, naso-oropharynx dan dengan demikian untuk mencegah infeksi sistemik serta mempercepat pemulihan pasien COVID-19. Mekanisme kerja obat kumur povidone iodine yakni oksidasi asam amino dan asam nukleat mikroorganisme sehingga menyebabkan gangguan metabolism dan destabilisasi membran sel. Pelepasan yodium bebas dari larutan PVP-I yang kemungkinan menyerang protein permukaan virus yang terbungkus envelope dan menghancurkan membrane fosfolipid dengan bereaksi dengan ikatan karbon tak jenuh. Efek virusidal pada obat kumur povidone iodine konsentrasi encer tidak menunjukkan bukti toksisitas pada silia pernapasan ataupun kerusakan mukosa.
\end{abstract}

Kata kunci: COVID-19; obat kumur povidone iodine; PVP-I

\section{THE EFFECTIVENESS OF POVIDONE IODINE (PVP-I) MOUTHWASH TO MINIMIZE VIRAL LOAD AND TRANSMISSION OF COVID-19 THROUGH DROPLET}

\begin{abstract}
WHO has declared COVID-19 a global pandemic. Until now, the number of confirmed positive cases in Indonesia is 1,051,795 cases with a death toll of 29,518. One of the most widely available broad-spectrum antimicrobial mouthwashes for reducing pathogens is the povidone iodine (PVP-I) mouthwash. PVP-I is known to have strong microbicidal activity. The purpose of this study was to determine the effectiveness of PVP-I mouthwash to minimize viral load and transmission of COVID-19 through droplets. This article was compiled by searching for literature sources using the NCBI, PubMed, Google Scholar, Research Gate and Science Direct databases. There were 39 articles published in 2015 to 2021 using keywords related to the title, namely PVP-I, povidone iodine mouthwash, COVID-19. After being selected based on the focus of the discussion on the effectiveness of PVP-I mouthwash in minimizing viral load
\end{abstract}


and transmission of COVID-19 through droplets, the authors used 22 articles as the main reference. The use of PVP-I as a mouthwash is recommended to reduce viral load in the oral cavity, naso-oropharynx and thus to prevent systemic infections and speed up recovery in COVID-19 patients. The mechanism of action of povidone iodine mouthwash is the oxidation of amino acids and nucleic acids of microorganisms, causing metabolic disorders and cell membrane destabilization. The release of free iodine from the PVP-I solution is likely to attack the viral surface envelope proteins and destroy the phospholipid membrane by reacting with unsaturated carbon bonds. The viralidal effect of a diluted povidone iodine mouthwash has shown no evidence of toxicity to respiratory cilia or mucosal damage.

Keywords: COVID-19; povidone iodine mouthwash; PVP-I

\section{PENDAHULUAN}

WHO telah menyatakan COVID-19 sebagai pandemi global sejak Maret 2020 (WHO, 2020). Hingga 5 Januari 2021, lebih dari 4 juta kasus baru dilaporkan secara global, dengan angka kematian meningkat 3\% menjadi 76.000. Hal ini menjadikan jumlah kumulatif lebih dari 83 juta kasus yang dilaporkan dan lebih dari 1,8 juta kematian secara global sejak dimulainya pandemi (WHO, 2021). Hingga saat ini jumlah kasus yang terkonfirmasi positif di Indonesia sebanyak 1.051.795 kasus dengan jumlah kematian sebesar 29.518 jiwa (Kemenkes RI, 2021).

COVID-19 disebabkan oleh virus SARS-CoV 2 yang merupakan $\beta$ family coronavirus, hanya virus corona keluarga $\alpha$ dan $\beta$ yang dapat menginfeksi manusia (Wang, 2020). SARS-Cov 2 masuk ke tubuh manusia melalui reseptor coronavirus yakni reseptor angiotensin converting enzyme (ACE) 2, reseptor ini banyak terdapat di tubuh terutama di sel epitel dari kelenjar ludah yang menjadi target utama virus COVID-19. Viral load tertinggi terdapat di nasofaring dan air liur manusia. Menurut penelitian, terdapat $1,2 \times 108$ salinan infektif / $\mathrm{mL}$ virus COVID-19 pada air liur pasien yang diuji (To, 2020). Viral load tertinggi terdapat di nasofaring, dan air liur manusia. Diketahui bahwa viral load pasien asimtomatik dan simptomatik tidak jauh berbeda, hal ini menunjukkan potensi penularan pada pasien simtomatik maupun asimptomatik (Phan, 2020).

Air liur berperan penting dalam transmisi infeksi melalui droplet (Yan, 2018). Aerosol adalah zat berbentuk cair atau partikel padat (berukuran kurang dari $5 \mu \mathrm{m}$ ) yang tetap tersuspensi di udara dalam waktu yang lama. Aerosol pembawa virus dapat masuk ke tubuh manusia yang sehat melalui inhalasi hidung atau mulut (virus COVID-19 dapat menyebar hingga 1 meter dalam keadaan bernapas normal), bersin dan batuk, atau melalui kontak dengan mulut, hidung, dan mukosa mata. Hal ini memungkinkan penyeberan virus terjadi secara cepat di masyarakat (Schroter, 2020; Christian, 2020).

Penelitian-penelitian mengenai evaluasi terapi dan pengembangan vaksin sedang gencar dilakukan, namun intervensi ini tergolong mahal dan memakan waktu. Mengingat angka kasus dan kematian yang terus meningkat dengan tajam, dibutuhkan respons cepat dalam menanggapi pandemi COVID-19 ini. Oleh karena itu, terapi alternatif dan tindakan pencegahan diperlukan untuk mempercepat melandaikan kurva epidemiologi. Disinfektan berbasis PVP-I sudah tersedia secara luas dan dapat dengan mudah diperoleh, sehingga memungkinkan untuk 
diintegrasikan ke dalam pengendalian infeksi yang ada protokol di rumah sakit dan pengaturan komunitas.

Penulis mengumpulkan informasi mengenai efek obat kumur pada virus di rongga mulut untuk mengetahui keefektivan penggunaan obat kumur di rongga mulut, terutama virus yang memiliki struktur serupa. Semua artikel yang tersedia tentang efek berbagai jenis obat kumur dan pengurangan viral load yang efektif di mulut. Penularan penyakit melalui aerosol, droplet dan air liur di lingkungan rumah sakit dapat dikurangi dengan mengidentifikasi keefektivan obat kumur dalam mengurangi viral load Virus COVID19. Oleh karena itu, penulis tertarik untuk melakukan penelitian mengenai efektivitas obat kumur PVP-I dalam meminimalisir viral load dan transmisi COVID-19 melalui droplet.

\section{METODE}

Artikel ini disusun dengan mencari sumber literatur melalui Springer dan Science Direct sebanyak 21 artikel yang diterbitkan pada tahun 2015 hingga 2021 menggunakan kata kunci yang berkaitan dengan judul yaitu PVP-I, obat kumur povidone iodine, COVID19. Sumber pustaka tersebut ditelaah dengan melakukan pengumpulan, evaluasi, dan mengembangkan hasil penelitian yang pernah ada pada topik tersebut.

\section{HASIL}

Penelitian Choudhury et al (2021) 606 pasien dibagi dalam 2 grup yakni grup A dan grup B. Di Grup A, 303 pasien menggunakan obat kumur, obat tetes hidung dan tetes mata dengan povidone iodine $1 \% 4$ jam setiap hari selama 4 minggu serta pengobatan simptomatik sesuai kebutuhan. Di Grup B 303 pasien disarankan menggunakan obat kumur, rongga hidung dan cuci mata dengan air hangat 4 jam setiap hari selama 4 minggu dan pengobatan simptomatik sesuai kebutuhan. Hasil dalam penelitian ini menunjukkan bahwa $2,64 \%$ pasien positif pada hari ke-7 pada Grup A dan 70,30\% positif. 3,30\% pada Grup B. 3,7\% pasien rawat inap kelompok A membutuhkan dukungan oksigen (dengan ventilator mekanis dan / atau kanula hidung aliran tinggi dan / atau masker non rebreather dan / atau masker wajah dan / atau kanula hidung) sedangkan $20,79 \%$ pasien dari kelompok B membutuhkan dukungan oksigen. Tingkat mortalitas didapatkan lebih tinggi 5,6\% pada kelompok B daripada $0,66 \%$ pada kelompok A. Kelompok pasien yang menggunakan PVP-I $1 \%$ telah menunjukkan penurunan yang signifikan pada mortalitas, morbiditas dan serta beban keuangan rumah sakit dalam situasi yang sulit ini.

Dalam penelitian yang dilakukan Khan (2020), semua sampel yang merupakan pasien dan petugas kesehatan diminta untuk menilai rasa ketidaknyamanan setelah berkumur dengan PVP-I. Dari 315 pasien, 308 pasien diantaranya merasa nyaman dengan penggunaan obat kumur PVP-I. 17 petugas kesehatan menggunakan tetes hidung PVP-I 0,5\% dan obat kumur. Tidak ada alergi yang dilaporkan oleh pasien dan petugas kesehatan dalam penelitian ini (Khan, 2020).

Challacombe (2020) telah meneliti peran potensial dari povidone iodine (PVP-I) dalam pengurangan risiko infeksi silang dokter gigi dan petugas kesehatan lain dari COVID-19. PVP-I memiliki aktivitas anti-virus yang lebih baik daripada antiseptik lain seperti klorheksidin, dan telah terbukti efektif sebagai virusidal in vitro melawan virus 
korona serupa (SARS-CoV dan MERS$\mathrm{CoV}$ ) 4, Walaupun hal tersebut belum diuji secara langsung dengan virus COVID-19. PVP-I telah terbukti sebagai terapi yang aman bila digunakan sebagai obat kumur atau diminum. Dari penelitian Eggers et al. (2018) diketahui penurunan titer virus korona mecapai lebih dari 99,99\% setelah penggunaan mouthwash Povidone iodine (Eggers, 2018).

Studi yang dilakukan oleh Anderson et al (2020) menunjukkan bahwa PVP-I memiliki aktivitas virusidal dalam melawan SARS-CoV-2. Keempat produk yang diuji coba [larutan antiseptic (PVP-I 10\%), pembersih kulit (PVP-I 7.5\%), gargle dan mouthwash (PVP-I 1\%) dan semprotan tenggorokan (PVP-I 0,45\%)] aktivitas virucidalnya mencapai angka $99,99 \%$ dalam melawan SARS-CoV-2. Hal ini menunjukkan aktivitas virusidal yang cepat dan efektif dari Produk PVP-I dalam melawan SARS-CoV-2 (Anderson, 2020). Terdapat perbedaan yang signifikan dalam pengurangan viral load antara kelompok yang diberikan intervensi obat kumur dan kelompok kontrol pada semua artikel yang ditinjau.

\section{PEMBAHASAN}

Obat kumur povidone iodine / PVP-I adalah salah satu obat kumur antimikroba spektrum luas yang paling banyak tersedia untuk mengurangi patogen. PVP-I (polivinilpirolidon yodium, Povidine iodine) adalah kompleks povidone, molekul pembawa, dan yodium yang larut dalam air dan diketahui memiliki aktivitas mikrobisidal yang kuat. Formulasi PVPI telah digunakan secara luas selama 60 tahun karena aktivitas antimikroba spektrum luasnya dan profil keamanan yang telah ditetapkan (Vogget, 2017;
Egger, 2018). PVP-I tercantum dalam Daftar Obat Esensial WHO, yang mengidentifikasi obat-obatan penting yang diperlukan dalam sistem kesehatan fungsional. Obat kumur PVP-I juga termasuk dalam WHO R\&D blueprint untuk terapi eksperimental melawan COVID-19 (WHO, 2020). Selain aktivitas antibakteri dan antijamur, PVP-I juga menunjukkan aktivitas in vitro terhadap berbagai virus, termasuk SARS-CoV terkait dan MERS-CoV (Eggers, 2015; Anderson, 2020).

Mekanisme kerja obat kumur povidone iodine yakni oksidasi asam amino dan asam nukleat mikroorganisme sehingga menyebabkan gangguan metabolism dan destabilisasi membran sel (Nagatake, 2012). Penelitian telah melaporkan bahwa PVP-I memiliki lebih banyak sifat antivirus dibandingkan obat kumur lainnya. Larutan PVP-I telah lama dikenal, terutama pada konsentrasi encer $(0,001 \%)$. Dari hasil penelitian diketahui bahwa efek virusidal lanjutan pada obat kumur povidone iodine konsentrasi encer tidak menunjukkan bukti toksisitas pada silia pernapasan ataupun kerusakan mukosa (Wu, 2020).

Efek antivirus obat kumur PVP-I diketahui melalui pelepasan yodium bebas dari larutan PVP-I yang kemungkinan menyerang protein permukaan virus yang terbungkus envelope dan menghancurkan membrane fosfolipid dengan bereaksi dengan ikatan karbon tak jenuh (Park, 2020; Walls, 2020; Bigliardi, 2017). Telah dibuktikan bahwa pengikatan yodium dengan komponen lipid virus yang diselimuti envelope meningkatkan kerentanan terhadap virus dibanding jika berikatan dengan virus yang tidak terbungkus envelope ( $\mathrm{Lu}, 2020)$. Virus COVID-19 termasuk dalam famili virus 
korona RNA untai tunggal yang terbungkus envelope. Beberapa penelitian terbaru menunjukkan bahwa PVP-I menonaktifkan MERS-Cov dan SARS-Cov yang memiliki genom yang hampir identik dengan virus COVID-19 (Van, 2020). PVP-I konsentrasi 0,23$1 \%$ mengurangi infektivitas di bawah tingkat yang dapat dideteksi dalam waktu 2 menit (Eggers, 2015). Dalam beberapa bulan terakhir, kefektivan terhadap larutan PVP-I telah dikonfirmasi untuk virus COVID-19. Setelah 30 detik, aktivitas virucidal $\geq$ 99,99\% terhadap COVID-19 ditemukan untuk PVP-I $1 \%$ mouthwash dan 0,45\% PVP-I nasal spray. Viral load COVID19 tinggi di rongga hidung, nasooropharynx, jaringan mulut, sel bersilia dan sel goblet dalam epitel pernafasan hidung yang memiliki ekspresi ACE2 tertinggi, reseptor utama virus COVID19 (Pelletier, 2020). Larutan PVP-I 0,5$10 \%$ menonaktifkan reseptor ACE2 dari sel inang.

Penelitian Choudhury (2020), pasien Grup A (mereka yang menggunakan PVP-I 1) dibandingkan dengan Grup B (mereka yang hanya menggunakan air hangat) memiliki outcome yang lebih baik dalam hasil tes RT-PCR, kematian, jumlah hari rawat inap dengan atau tanpa dukungan oksigen. Di sisi lain, 2,64\% pasien positif pada hari ke-7 pada Grup A dan 70,30\% positif pada Grup B. Jadi, jelas bahwa 1\% PVP-I secara signifikan terbukti mengurangi viral load di rongga mulut, rongga hidung, dan naso-orofaring (Choudhury, 2020). Informasi ini sejalan dengan studi in vivo yang dilakukan oleh Martinez Lams dkk pada Juni 2020; penelitian ini bertujuan untuk mengetahui pengaruh PVP-I $1 \%$ terhadap pasien positif COVID-19. Mereka mengevaluasi dan membandingkan viral load air liur pasien tersebut setelah penggunaan $1 \%$ PVP-I 1 menit dan efeknya bertahan selama 3 jam (Martinez, 2020).

Studi terbaru yang menguji stabilitas SARSCoV-2 dalam berbagai kondisi lingkungan, termasuk dalam paparan PVP-I dan disinfektan lainnyan selama 5, 15 dan 30 menit (Chin, 2020). Hasil menunjukkan bahwa SARS-CoV-2 dapat bertahan selama 6-7 hari pada beberapa permukaan (tahan karat baja dan plastik), tetapi virus dapat dinonaktifkan oleh sejumlah disinfektan umum. Virus itu tidak terdeteksi dengan paparan 5 menit atau lebih saat diuji dengan PVP-I (7,5\%), menunjukkan potensi penggunaan PVP-I dalam prosedur desinfeksi(Chin, 2020). Studi sebelumnya dengan produk PVP-I pada SARS-CoV dan MERS-CoV mendemonstrasikan aktivitas virucidal cepat meskipun terdapat zat yang dapat mengganggu seperti eritrosi atau disimulasikan dalam kondisi 'kotor'. Tidak ada perbedaan yang diamati pada log kill virus dalam kondisi bersih versus kotor, hal ini menunjukkan bahwa zat yang mengganggu tidak menurunkan aktivitas antivirus dari PVP-I. Dalam studi ini, PVP-I dapat menonaktifkan dengan cepat (Penurunan C $4 \log 10$ dalam TCID50 / $\mathrm{mL}$ pada titer virus) SARS-CoV dan MERS-CoV dalam waktu kontak 15 detik.

Hou et al baru-baru ini menunjukkan bahwa virus COVD-19 awalnya menginfeksi sel rongga hidung bersilia. Virus ini kemudian menyebar melalui nasal-oropharynx ke paru-paru melalui aspirasi mikro dan menyebabkan infeksi paru yang kemudian membentuk keterlibatan sistemik melalui penyebaran hematogen (Hou et al, 2020). Penggunaan PVP-I $1 \%$ sebagai obat kumur, obat tetes hidung dan mata 
juga telah direkomendasikan untuk mengurangi viral load di rongga mulut, naso-oropharynx dan dengan demikian untuk mencegah infeksi sistemik serta mempercepat pemulihan pasien COVID-19 (Kirk-Bailey, 2020).

Sebuah studi rumah sakit tentang COVID-19 merekomendasikan penggunaan obat kumur povidone iodine untuk pasien dan tenaga kesehatan yang kontak langsung dengan pasien COVID-19 [49]. Berkumur dengan obat kumur yang mengandung povidone iodine juga disarankan dalam beberapa penelitian untuk mengurangi viral load (Eggers, 2015; Eggers, 2018; Khan, 2020). Prosedur ini mengurangi risiko penyebaraan virus saat batuk, bersin, dan berbicara. Dengan demikian mungkin efektif dalam mengendalikan pandemi COVID-19.

\section{SIMPULAN}

Penggunaan PVP-I sebagai obat kumur direkomendasikan untuk mengurangi viral load di rongga mulut, nasooropharynx dan dengan demikian untuk mencegah infeksi sistemik serta mempercepat pemulihan pasien COVID-19. Mekanisme kerja obat kumur povidone iodine yakni oksidasi asam amino dan asam nukleat mikroorganisme sehingga menyebabkan gangguan metabolism dan destabilisasi membran sel. Pelepasan yodium bebas dari larutan PVP-I yang kemungkinan menyerang protein permukaan virus yang terbungkus envelope dan menghancurkan membrane fosfolipid dengan bereaksi dengan ikatan karbon tak jenuh. Efek virusidal pada obat kumur povidone iodine konsentrasi encer tidak menunjukkan bukti toksisitas pada silia pernapasan ataupun kerusakan mukosa.

\section{DAFTAR PUSTAKA}

American Dental Association (ADA). (2020). Interim Guidance for Minimizing Risk of COVID-19 Transmission 2020. https://bit.ly/3bskHOx

Anderson, D. E., Suvalingam, V., Kang, A. E. Z., Ananthanarayanan, A., et al. (2020). Povidone-Iodine Demonstrates Rapid In Vitro Virucidal Activity Against SARSCoV-2, The Virus Causing COVID-19 Disease. Infect Dis Ther, 9, 669-675. https://doi.org/10.1007/s40121020-00316-3

Bigliardi, P. L., Alsagoff, S. A. L., ElKafrawi, H. Y., Pyon, J. K., Wa, C. T. C \& Villa, M. A. (2017). Povidone Iodine in Wound Healing: A Review of Current Concepts and Practices. International Journal of Surgery, 44, 260-268.

Chin, A. W. H., Chu, J. T. S., Perera, M. R. A., et al. (2020). Stability of SARS-Cov-2 in Different Environmental Conditions. Lancet Microbe, 1(10).

Choudhury, I. M., Shabnam, M., Ahsan, T., Kabir, S., et al. (2020). Effect of $1 \%$ Povidone Iodine Mouthwash/Gargle, Nasal and Eye Drop in COVID-19 Patient. Bioresearch Comm, 919-923.

Eggers, M., Eickmann, M., \& Zorn, J. (2015). Rapid and Effective Virucidal Activity of PovidoneIodine Products Against Middle East Respiratory Syndrome Coronavirus (MERS-Cov) and Modified Vaccinia Virus Ankara (MVA). Inf Dis Ther, 4(4), 491501. 
Eggers, M., Koburger-Janssen, T., Eickmann, M., \& Zorn, J. (2018). In Vitro Bactericidal and Virucidal Effcacy of Povidoneiodine

Gargle/Mouthwash Against Respiratory and Oral Tract Pathogens. Infect Dis Ther, 7, 249-259.

Hou, Y. J., Okuda, K., Edwards, C. E., Martinez, D. R., Asakura, T., Dinnon, I. I. I. K. H., et al. (2020). SARS-CoV-2 Reverse Genetics Reveals a Variable Infection Gradient in the Respiratory Tract. Cell. 2020.

Khan, M. M. S. R., Parab., Paranjape, M., Paranjape., \& Mandar. (2020). Repurposing $0.5 \%$ Povidone Iodine Solution in Otorhinolaryngology Practice in Covid 19 Pandemic. American Journal of Otolaryngology, 41(5), 102618.

doi:10.1016/j.amjoto.2020.10261 8

Kirk-Bailey, J., Combes, J., Sunkaraneni, S., \& Challacombe, S. (2020). The Use of Povidone Iodine Nasal Spray and Mouthwash during the Current COVID-19 Pandemic for the Reduction of Cross Infection and Protection of Healthcare Workers.

https://papers.ssrn.com/sol3/paper s.cfm?abstract_id=3563092

Lachapelle, J. M. (2018). A Comparison of the Irritant and Allergenic Properties of Antiseptics. Eur $J$ Dermatol, 24(1), 3-9.

Park, S. E. (2020). Epidemiology, Virology, and Clinical Features of Severe Acute Respiratory Syndrome-Coronavirus-2 (SARS-
Cov-2; Coronavirus Disease-19). Clinical and experimental pediatrics, 63(4), 119.

Phan, L. T., Nguyen, T. V., Luong, Q. C., et al. (2020). Importation and Human-To-Human Transmission of a Novel Coronavirus in Vietnam. N Engl J Med, 382(9), 872-874.

R, S., Christian, M. D. (2020). Practical Recommendations for Critical Care and Anesthesiology Teams Caring for Novel Coronavirus (2019-Ncov) Patients. Can J Anesth, 67, 1-9

Schroter, R. C. (2020). Social Distancing for Covid-19: is 2 Metres Far Enough? BMJ. doi:10.1136/bmj.m2010

To, K. K. W., Tsang, O. T. Y., Yip, C. C. Y., et al. (2020). Consistent Detection of 2019 Novel Coronavirus in Saliva. Clin Inf Dis. doi:10.1093/cid/ciaa149

Vogt, P. M., Hauser, J., Mueller, S., Bosse, B., \& Hopp. M. (2017). Efficacy of Conventional and Liposomal Povidoneiodine in Infected Mesh Skin Grafts: An Exploratory Study. Infect Dis Ther, 6(4), 545-55.

Walls, A. C., Park, Y. J., Tortorici, M. A., Wall, A.,, McGuire, A. T., \& Veesler, D. (2020). Structure, Function, and Antigenicity of the SARS-Cov-2 Spike Glycoprotein. Cell.

Wang, D., Hu, B., Hu, C., et al. (2020). Clinical Characteristics of 138 Hospitalized Patients with 2019 Novel Coronavirus-Infected Pneumonia in Wuhan, China. Jama. 
World Health Organisation. (2020). WHO R\&D Blueprint COVID 19 Experimental Treatments: World Health Organisation. 2020. https://www.who.int/docs/ defaultsource/coronaviruse/covidclassification-oftreatment- typesrev.pdf.

Wu, Z., \& McGoogan, J. M., (2020). Charactristics of and Important Lessons from the Coronavirus Disease 2019 (COVID-19) Outbreak in China: Summary of a Report Of 72314 Cases From the Chinese Center for Disease Control and Prevention. Jama. 